\title{
FOOD RESEARCH IN CROATIAN ETHNOLOGY
}

MELANIJA BELAJ

This paper provides an overview of food culture research in Croatian ethnology. Ethnological studies of culture of food in Croatia were conducted within different approaches and analytical procedures: from the simple collection of facts about traditional rural dishes, through cultural-historical searches for the background of certain elements, to contemporary anthropological approaches that perceive food culture within a larger social context (for example eating habits during wartime, within the Croatian war ethnography). Keywords: food research, food culture, Croatian ethnology.
Članek posreduje pregled raziskav kulture prehranjevanjav hrvaški etnologiji. Etnološke raziskave prehrane so bile na Hrvaškem opravljene z različnimi pristopi in analitičnimi postopki: od preprostega zbiranja dejstev o tradicionalnih jedeh na podežlju, kulturnozgodovinskega iskanja ozadja posamičnih sestavin do sodobnih antropoloških pristopov, $k i$ kulturo hrane dojemajo v širšem socialnem kontekstu (npr. prehranske navade med vojno v hrvaški etnografiji vojne). Ključne besede: raziskave prehrane, kultura prehranjevanje, hrvaška etnologija.

\section{INTRODUCTION}

This text presents a brief overview of the research on food culture in Croatian ethnology, i.e. cultural anthropology. Until recently, food research was undertaken following different approaches and analytical scopes, from the simple gathering of facts on traditional village food and nutrition, cultural-historical inquiries about the origins of certain elements, to contemporary anthropological approaches that place food culture within entire social contexts and particular periods. Examples of this include nutrition during specific war circumstances in the ethnography of the Croatian war and nutrition in the Baroque - both studies of Nives Rittig-Beljak (Beljak 1996, 2005; Rittig-Beljak 2006, 2007). Croatian ethnology did not consistently follow other trends in the systematic study of food, which in European ethnologies began in the 1960s. I am making reference here to the works of authors who helped develop ethnographic and cultural-anthropological perspectives in studies of food culture both in terms of theory and methodology.

To begin I would like to call attention to the work of Günter Wiegelmann who in his book titled Alltags-und Festspeisen. Wandel und gegenwärtige Stellung (Everyday and Festive Food. Changes and Contemporary Situation, 1967) described and provided insights into changes in eating and meal patterns of Germans during the 18th and 19th centuries. In his research, Wiegelmann draws on the work of historians, thus reconstructing the eating patterns and paths of specific victuals through time and space. Furthermore, I would like to refer to the works of French scholars - the Claude Lévi-Strauss and Roland Barthes who contributed to the development of the structural perspective in food culture research, which was, in my opinion, finally reaffirmed by a British anthropologist Mary Douglas. 
The analysis of food culture in these terms developed in Croatian ethnography only later on. Research of nutritional practices and of the relatively neglected drinking culture is parts of the ethnology of everyday life that became an area of broad anthropological interest by the 1970s. The ethnology of everyday life entered the field of Croatian ethnological interest with the work of Dunja Rihtman-Auguštin (1988). In researching food culture in the 1980s and 1990s, ethnologists moved beyond the descriptive level and began observing food and drink from the regional perspective, seeing the possibility of comparisons as well as the coexistence of diverse approaches and interpretations (in conjunction with the specifics of historical and social contexts and cultural differences).

Notwithstanding this, in this overview of the research of food culture in Croatia I begin with the period when Antun Radić was active and continue with Milovan Gavazzi and Branimir Bratanić. This exploration did not look for studies on food and nutrition in the beginnings of ethnological interests in Croatia but relied on sources and materials that appeared within ethnology as a discipline, marked by the contributions of the aforementioned scholars who started studying food and nutrition while researching traditional culture, i.e. the culture of the peasantry in the Croatian territory.

\section{DESCRIPTIVE LEVEL - CULTURAL HISTORICAL RESEARCH}

The Yugoslav Academy of Sciences and Arts, the predecessor of the Croatian Academy of Sciences and Arts, established the Committee of Folk Life and Customs in 1888, which started publishing Zbornik za narodni život i običaje (Almanac of Folk Life and Customs) in 1897. With the founding of the Committee, the systematic and organized collection of ethnographic and folkloristic material on folk life, customs and traditional culture began in Croatia. The foundation of that work was set down by Antun Radić, who published in 1897 the booklet titled Osnova za sabiranje i proučavanje grade o narodnom životu (Foundation for the Collection and Study of Materials on Folk Life). Soon, numerous manuscripts started arriving at the Academy from different parts of Croatia, in which educated people such as priests, teachers, veterinarians and notaries wrote down answers to questions from Osnova.

Osnova of Antun Radić was divided into several major thematic parts. The first part consists of introductory deliberations about basic understandings of the term folk, and the second one comprises three smaller chapters; they propose entries on how to describe the natural environment around people and the physical constitution of people and language. Data about food and drink can be found in Part Two of the second unit of Osnova, in the column "Vital items," under "Food and utensils," and in the column "Work". However, because food and drink are parts of life and of yearly customs, data about them can be found in other units of Osnova.

When browsing through years of ethnographic material where data on traditional village food can be found, we cannot neglect the Archive of the Department of Ethnology and Cultural Anthropology of the Faculty of Humanities and Social Sciences, which has 
been in operation from the establishment of the department onwards (Milovan Gavazzi founded the Department of Ethnology in 1927). Invaluable is the project Etnološki atlas Jugoslavije (Ethnological Atlas of Yugoslavia), set up by Branimir Bratanić. A noteworthy part of the material includes questionnaires of the Ethnological Atlas of Yugoslavia with data collected about the elements of traditional culture in the former Yugoslavia from the 1960s; the goal was publishing ethnological maps. Questionnaires contained 157 topics that encompassed the material, social and spiritual culture of Croats and other South Slavs. The topic of food was dealt with in the second volume in about ten questions. Some of the topics were: brick ovens outside of the house, supply of water, hearth, utensils at the hearth, peka/cooking, meals during the day and customary meals, bread and bread substitutes, bread shapes and special kinds of breads, meal and meal-like foods, dishes made of dough, dairy foods, cheeses and other milk produce, butter and butter oil, meat preservation, ritual meals, drinks and baked goods, common drinks and making brandy. We should turn attention to the studies of Milovan Gavazzi and his contribution to food research in Croatian ethnology. He published several essays and studies about food and nutrition. In his article titled "Seoska prehrana u Jugoslaviji - Izvori i istraživanja”(Peasant Nutrition in Yugoslavia - Sources and Researches), Gavazzi claims that all collected material on nutrition from any region, nation or culture can be divided, viewed and judged from several angles:

1. from a cultural-geographical perspective, i.e. as a regional division of the given area;

2. from a cultural-historical perspective, with regard to the historical path of particular kinds of dishes, their origins, i.e. antiquity;

3. from the perspective of social connectedness and the consequent social role of particular dishes and drinks;

4. through the classification of dishes and drinks (Gavazzi 1978a: 108).

He also believed that the first, third and fourth aspect relate to systematizing and orientation, whereas the second is ethnological, i.e. comparative-cultural. One example of such a comparative-culturological method of researching food and nutrition was his study "Oko podrijetla jednog blagdanskog peciva južnih Slavena” (About the Origin of One Holiday Baked Good of South Slavs) (Gavazzi 1978b).

Other perspectives that Gavazzi referred to in his article are those from which food and nutrition were continually researched in Croatian ethnology of the 1970s, '80s and '90s. These include the geographical distribution of specific dishes, their social role, and their grouping according to certain kinds of foods and drinks; nutrition is linked to customs, yearly or once in a lifetime, such as the study of Branko Đaković (1985) titled "Hrana i piće u posmrtnim obredima, a posebno kao viaticum" (Food and Beverages in Death Ceremonies, Especially as a Viaticum). Many studies analyze particular dishes or ingredients from an ethnological perspective, such as the work of Manda Svirac (1996) titled "Uloga kruha u običajima Hrvata" (The Role of Bread in Customs of Croats) or that of Zdenka Lechner (1985) titled "Paprenjaci u Vrbovi” (Peppery Biscuits in Vrbova). 
A significant group of studies is focused on a particular region or place where nutrition is one of the topics that were the subject of study (such as the research undertaken by a group from the Ethnographic Museum Zagreb and their associates in the Zagreb environs). Other research includes the following works that target nutrition in a particular region: "Tradicijska prehrana na otocima Silbi i Olibu" (Traditional Nutrition on the Islands of Silba and Olib) by Aleksandra Lazarević (1985); "Seoska prehrana u Baranji" (Village Nutrition in Baranja) by Božica Somek-Machala (1986), “Žumberak - tradicijski okviri prehrane stanovništva” (Žumberak - Traditional Nourishment of the Population) by Mirjana Randić (1996), and "Za creskim stolom: tradicijska prehrana u strukturi lokalne kulture" (At the Table of the Island Cres: Traditional Nourishment in the Structure of Local Culture) by Aleksandra Muraj (1997).

Surveys from comprehensive ethnographic monographs that deal with the issue of regional distribution should also be mentioned. In the edited volume titled Etnografija. Svagdan i blagdan hrvatskoga puka (Ethnography: Everyday and Holiday of the Croatian Folk, 1998), ethnologist Aleksandra Muraj (in her contribution titled "Obrisi svakidašnjeg života" (Contours of Everyday Life) gives an overview of nutrition in the Adriatic, Pannonian and littoral cultural zones following the customary division of cultural areas within which traditional culture had been researched in earlier studies. Mirjana Randić (2006) in the book titled Svijet hrane u Hrvatskoj (The world of food in Croatia) gave an overview of nutritional traditions in accordance with nutritional models of the littoral area, Adriatic hinterland, mountainous area, and the central and low lying areas of Croatia. This division was quite differentiated, acknowledging that views on researching traditional culture, including food research, were gradually changing.

In the majority of the studies mentioned above, the authors used, in addition to materials collected during their own fieldwork, ethnographic materials from manuscripts of the Zbornik za narodni život i običaje, i.e. monographs that were mostly written according to A. Radićs Osnova and the collected material from the questionnaire of the Ethnological Atlas of Yugoslavia. They used older ethnographic materials as the foundation for their research or compared it with the situation found during their own fieldwork. In that way, they searched for traditional elements in the contemporary context. The descriptive level and the customary and inherited research frameworks regarding the approach to food were gradually improved in the 1990s. Until then, research of nutrition relied on historical sources and was guided by cultural-historical goals, i.e. the analyses of the origins of cultural elements of traditional nutrition or of their geographical distribution. That limitation suited the general desire to reconstruct the past of the national culture based on traces in contemporary customs. In the early 1990s, new research interests in food and drinking culture became evident, including tracking the continuities and changes in traditional nutrition in particular social contexts, the study of hierarchical, gender and regional differences and a focus on the symbolic and nutritive role of food in the social moment marked by cultural meetings and interferences. 


\section{NEW APPROACHES TO THE FOOD CULTURE}

In support of the latter statement, I wish to mention research of the drinking culture, more precisely the production of alcoholic beverages. Such research found place within the works on the economy of particular regions, especially in studies of fruit and wine production (Cvetan 1991; Somek-Machala 1992; Šestan 1992) and in studies on ethnomedicine and folk piety. They followed the aforementioned guidelines for researching food and nutrition based on the foundation laid by Milovan Gavazzi. However, research into drinking culture shifted direction slightly in the 1990s. The work of two authors is illustrative in this respect. Dragica Cvetan (1991) researched wine growers' huts of the vineyards in the Plešivica hills and in particular their role in social life, while Olga Supek-Zupan (1979, 1987) in her research of the economy of the Prigorje village touched upon the topic of the culture of family production and consumption of alcohol. Their studies are inspiring because of the way in which they approached the topic of wine production, distancing themselves from the descriptive level and viewing wine production in a wider social context. Olga SupekZupan (1979) saw wine as a facilitator of communication between people, while Dragica Cvetan saw wine production and wine growers' huts (the fabled klijet) as a mark of social life and as a symbol of the regional identity of the people of Prigorje.

I took this short digression to state a new approach to food culture, which is most pronounced in the writings of Mirjana Randić from the Ethnographic Museum Zagreb and Nives Rittig-Beljak from the Institute of Ethnology and Folklore Research. The two of them were the curators of a great exhibition held at the Ethnographic Museum Zagreb titled Svijet hrane u Hrvatskoj (The World of Food in Croatia, 2007), and they were also the organizers of the 15th Conference of the International Commission for Ethnological Food Research on the subject of Mediterranean Food: Concepts and Trends held in Dubrovnik in 2004. Two conferences were organized within the mentioned exhibition. The topics were culinary tourism and the relationships that determine social asymmetry between the guest and the host as well as the ways that the culturally predetermined expectations of tourists affect the shaping and creation of what is offered to tourists. Tourism and cuisine make a special elaborate topic that enable the examination of a theoretical presumption that eating is a unique form of communication with the people and culture of the country we are visiting. On the other hand, experiments with new tastes in our own cuisines raise many questions about hybrid national culinary identity. In that way, culinary tourism combines personal experience with cultural and social attitudes towards food and beverages. We are faced with times when the presentation of Croatian culinary products will have to be molded according to the expectations of tourists, available supplies, and the influence of cultural tourism development strategies under implementation. Cultural tourism seeks for partners in the field of food research, and ethnologists are facing a request for assessing basic scientific terms and monitoring contemporary research trends. 
In addition to that, work on the systematization of the lexical material about food and drink began within the Institute of Ethnology's research project Kultura prehrane u ozračju društvenih promjena 20. i početka 21. stoljeća (Food Culture Within Social Changes of 20th and the Beginning of 21st Century, 2007-2012); the result will be a historical dictionary of culinary terminology with a presentation of terminology from sources written in the Croatian dialects and in the standard Croatian language from the 16th to the 20th century.

\section{CONCLUSION}

The voice of ethnologists and cultural anthropologists can be heard only at the margins and is not acknowledged by the scientific, economic and wider social community. It is also important to note the current engagement of ethnologists and cultural anthropologists of food and nutrition in the protection of the intangible cultural heritage. I wonder whether and to what extent their involvement is required and to what extent it is visible and valued; however, answering these questions will be possible only in the future.

Food is, in modern travelling cultures, a meeting point of the symbolic and physical, virtual and experiential, emotional and commercial dimensions of culture. We should develop the ethnology (or cultural anthropology) of food and nutrition within that frame, where connections can be found and a synthesis of diverse directions of the research given. Knowing the style of national nutrition is a significant contribution to the understanding of cultural identity at a time when cultural identity changes fast and when new forms of local authenticity are being created through the encounters of culture.

\section{REFERENCES}

Beljak, Nives

1996 Croatian Exiles from Vojvodina: Between War Memories and War Experience. In: Jambrešić Kirin, Renata and Maja Povrzanović (eds.), War, Exile, Everyday Life: Cultural Perspectives. Zagreb: Institute of Ethnology and Folklore Research, 173-179.

2005 Rječničko blago Gazophylaciuma (1740) u povijesti hrvatskog kulinarstva. Gazophylacium. Casopis za znanost, umjetnost, gospodarstvo i politiku 10 (1-2): 205-213.

Cvetan, Dragica

1991 Gorice, vino i klijet - simboli prigorskog regionalnog identiteta. In: Rihtman-Auguštin, Dunja (ed.), Simboli identiteta. Zbornik radova sa 23. kongresa Saveza etnoloških društava Jugoslavije. Zagreb: X-Press, 225-236.

Đaković, Branko

1985 Hrana i piće u posmrtnim obredima, a posebno kao viaticum. Etnološka tribina 15 (8): 77-84.

Gavazzi, Milovan

1978a Seoska prehrana u Jugoslaviji. In: Gavazzi, Milovan, Vrela i sudbine narodnih tradicija. Zagreb: Sveučilišna naklada Liber, $108-114$. 
1978b Oko podrijetla jednog blagdanskog peciva južnih Slavena. In: Gavazzi, Milovan, Vrela i sudbine narodnih tradicija. Zagreb: Sveučilišnna naklada Liber, 38-44.

Lazarević, Aleksandra

1984 Traditional nutrition on the islands of Silba and Olib. An attempt of interdisciplinary approach. Collegium antropologicum 8 (1): 117-122.

Lechner, Zdenka.

1985 Paprenjaci u Vrbovi. Etnološka tribina 8: 55-60.

Muraj, Aleksandra

1998 Obrisi svakidašnjeg života. In: Čapo Žmegač, Jasna et al. (eds.), Etnografija. Svagdan i blagdan hrvatskog puka. Zagreb: Matica hrvatska, 23-136.

1997 Za creskim stolom. Tradicijska prehrana u strukturi lokalne kulture. Etnološka tribina 20: $145-210$.

Radić, Antun

1897 Osnova za sabiranje i proučavanje grade o narodnom životu. (= Zbornik za narodni život i običaje Južnih Slavena, sv. II). Zagreb: Jugoslavenska akademija znanosti i umjetnosti.

Randić, Mirjana

1996 Žumberak - tradicijski okviri prehrane stanovništva. Sociologija sela 34 (133/134): 223-241.

2006 Hrvatska regionalna kuhinja. In: Rittig-Beljak and Randić 2006, 24-79.

Rihtman-Auguštin, Dunja

1988 Etnologija naše svakodnevnice. Zagreb: Školska knjiga.

Rittig-Beljak, Nives

2006 Umijeće kuhanja u baroku. In: Rittig-Beljak and Randić 2006, 79-91.

2007 Kuharica Nikole Zrinskog In: Puntijar, Matea i Zlatko Puntijar (eds.), Kuharska knjiga čakovečkog dvora obitelji Zrinski. Zagreb: V. O. Stari Puntijar, 1-9.

Rittig-Beljak, Nives and Mirjana Randić (eds.)

2006 Svijet hrane u Hrvatskoj. Zagreb: Etnografski muzej Zagreb.

Somek-Machala, Božica

1992 Vinogradarstvo sjeverozapadne Hrvatske u prošlosti. In: Obad, Željko (ed.), Martinje. Blagdan vina. Zagreb: Otvoreno sveučilište, 39-43.

1996 Seoska prehrana u Baranji. Studia ethnologica Croatica 4: 145-155.

Supek-Zupan, Olga

1979 Nacrt istraživanja jednog prigorskog sela. Narodna umjetnost 16: 57-77.

1987 Darivanje kao totalna komunikacija. Etnološka tribina 10: 7-19.

Svirac, Manda

1996 Uloga kruha i peciva u običajima Hrvata. (Doktorska disertacija.) Zagreb.

Šestan, Ivan

1992 Vino i tradicija. Katalog izložbe. Zagreb: Etnografski muzej.

\section{RAZISKAVE PREHRANE V HRVAŠKI ETNOLOGIJI}

Prispevek predstavlja kratek pregled raziskav o kulturi hrane v hrvaški etnologiji oz. kulturni antropologiji. Etnološke študije kulture hrane so bile na Hrvaškem izvedene iz različnih izhodišč in z različnimi analitičnimi postopki: od preprostega zbiranja dejstev o tradicionalnih jedeh na podeželju, prek kulturnozgodovinskih raziskav ozadja posamičnih kulturnih elementov do sodob- 
nih antropoloških pogledov na hrano v širšem socialnem kontekstu. Etnologi so starejše etnografsko gradivo uporabljali za podlago svojih raziskav ali pa so ga primerjali z ugotovitvami sodobnega terenskega dela. V tem smislu so iskali tradicionalne elemente v sodobnem kontekstu. Preseganje opisnosti in prevzetih raziskovalni vzorov sega v 90. leta prejšnjega stoletja. Dotlej so raziskave prehrane temeljile na zgodovinskih virih in so bile ujete $v$ kulturnozgodovinske analize o izvirih kulturnih elementov in tradicionalne prehrane ali njihove zemljepisne razširjenosti. $V$ 80. in 90. letih so začeli opazovati hrano in pijačo iz regionalne perspektive, upoštevali primerjave, študije pa kažejo tudi na sožitje različnih raziskovalnih pristopov in interpretacij, povezanih s posebnostmi zgodovinskih in družbenih kontekstov in kulturnih razločkov.

$V$ zadnjih desetletjih so novi pogledi razvidni v delu več raziskovalscev: gre za poglede, ki vztrajajo pri zasledovanju in razumevanju kontinuitete in sprememb $v$ tradicionalni hrani $v$ družbenem okviru; s tem se izrisujejo spolne in regionalne neenakosti kakor tudi simbolični in prehranski pomen jedi in pijač. Omogočajo tudi kritično analizo kulture prehranjevanja, ki je še zlasti pomembna, saj hrana sama ustvarja številne pomene in stem postaja simbol, skaterim je mogoče na različne načine rokovati $v$ sodobni kulturni politiki. Zaradi tega je pomembno, da raziskave hrane ne ostanejo obrobna tema v etnologiji in kulturni antropologiji, kakor je tudi pomembno, da vloga etnografske in kulturnoantropološke perspektive ne ostane zanemarljiva in nevidna.

Dr. Melanija Belaj, senior assistant, Institute of Ethnology and Folklore Research, Šubićeva 42, HR - 10000 Zagreb, Croatia, melanija@ief.hr 